\title{
A comparative analysis of strengths and weaknesses of corporate governance practices between two jurisdictions; UK and South Africa
}

\author{
King Costa*; Thelela Ngcetane-Vika**; \\ Global Centre for Academic Research
}

\begin{abstract}
This paper is an exploration of theoretical aspects underpinning the practice of Corporate Governance (CG) in the United Kingdom and South Africa. Because of several corporate scandals and failures in the twenty and twenty first siècles, Corporate Governance has been a significant and crucial subject and field of study in business schools in recent years. Leadership and Management of business entities and alignment to prescripts that are statutory formulated for prevention of corporate decline and enhancement of sound business principles continue to be highly contentious issues. A theoretical and exploratory narrative synthesis was conducted to unearth the strengths and weaknesses of contextual explication, practice and legal application of Corporate Governance in both the United Kingdom and South Africa. In terms of the UK, the study found out that the CG is designed and benchmarked on international best practice, seamlessly fitting within all the Codes on Key Aspects of Corporate Governance. Secondly, another major element of strengths determination were found to be inherent in the practice of voluntary compliance. However, the greatest criticisms of Corporate Governance theories in the UK was the fact that their focus is largely on public corporations, especially those listed in London stock exchange and thus, leave behind small and medium enterprises. The cultural diversity is also found to be a cause for concern in terms of practice and legal application. On the other hand, in South Africa, the study found out that consideration for diversity is one of the greatest strengths in CG practice and legal application, which is likely to contribute effectively to good and sound decision-making, reflective of all people. Weaknesses continue to be the delay in realisation of board equity in terms of gender while on the other hand, corruption and lack of adherence to retributive prescripts remain problematic.
\end{abstract}

Key words: Business Leadership, Corporate Governance, Corporate Scandals, Corruption 


\section{Introduction}

Corporate Governance ${ }^{1}$ has been both a topical and important issue in recent years, owing to many corporate scandals and failures in the twentieth and twenty first century, respectively. Some of these corporate scandals have been attributed to the failure of the board of directors to display fidelity to the company they lead. No doubt, board of directors are an important governance organ in a company. Thus, "corporate governance has become a contested and controversial issue" ${ }^{2}$ with the aim to align the interests of corporations, individuals and society." ${ }^{3}$ Corporate Governance (also referred hereinafter as CG) is hard to measure and its definitions vary ${ }^{4}$ but the most widely accepted definition is contained in the OECD ${ }^{5}$ which defines it as, "a set of relationships between a company's board, its shareholders and other stakeholders. It provides the structure through which the objectives of the company are set, and the means of attaining those objectives, and monitoring performance, are determined." Further, it can be defined as, "the system by which companies are directed and controlled." Thus, Corporate Governance has become a contentious discussion post Enron, ${ }^{8}$ Maxwell (UK), ${ }^{9}$ and Parmalat $^{10}$ cases and other major global financial crisis as these corporate scandals shone a light on corporate lapses and failures of greatest proportions. Some auditing firms were also found wanting as they enabled, through willingly collaborating, some corporations.

Globalisation and the interconnectedness of the world has brought to the fore the debate and call for global convergence in governance codes and rules. Global convergence ${ }^{11}$ defined as

\footnotetext{
${ }^{1}$ Christine A Mallin, Corporate Governance (5th edn, Oxford University Press 2016) 1.

2 Sanford M. Jacoby, 'Corporate Governance in Comparative Perspective: Prospects for Convergence' (2001) 11 $<$ http://papers.ssrn.com/sol3/papers.cfm?abstract id=285949> accessed 27 May 2021.

3 Sirdar Global Group, 'Two Cadbury quotes-and some commentary' (2017)<https://sirdargroup.com/twocadbury-quotes-and-some-commentary/\# > accessed 27 May 2021.

${ }^{4}$ Von Schnurbein G and Stühlinger S, 'Revisiting the Relationship of CSR and Corporate Philanthropy by Using Alignment Theory' (2015) CEPS Working Paper Series No. 6. Basel: CEPS< < https://ceps.unibas.ch/fileadmin/user upload/ceps/2 Forschung/Publikationen/Working Papers/06 Schnurbein Stuehlinger Revisiting the Relationship of CSR and Corporate Philanthropy by Using Alignment Theory.p $\underline{\mathrm{df}}>$ accessed 26 May 2021.

5OECD, 'Principles of Corporate Governance' (2015)<http://www.oecdilibrary.org/docserver/download/2615021e.pdf?expires=1466268869\&id=id\&accname=gu est\&checksum=77F 4E3153A36D69FE7BC5F54F7E67006 > accessed 27 May 2021.

${ }^{6}$ Ibid.

${ }^{7}$ Cadbury Report, 1992 < https://www.icaew.com/library/subject-gateways/corporate-governance/codes-andreports/cadbury-report> accessed 26 May 2021.

${ }^{8}$ Enron < https://www.thebalancesmb.com/sarbanes-oxley-act-and-the-enron-scandal-393497> accessed 27 May 2021.

${ }^{9}$ Maxwell Sheppard v. Maxwell, 384 U.S. 333 (1966)

${ }^{10}$ Ron Rimkus, 'Financial Scandals, Scoundrels \& Crises92016) CFA Institute < Parmalat

>https://www.econcrises.org/2016/11/29/parmalat/> acessed 27 May 2021.

11 Douglas M Branson, 'The Very Uncertain Prospect of Global Convergence in Corporate Governance' (2001) 34(2) CILJ 322
} 
"increased similarity in the governance practices in different jurisdictions,"12 through Multinational Corporations (MNCs). ${ }^{13}$ The CG global debate is a welcomed move in the efforts of international standardisation of CG and harmonisation of international laws. Thus, the call for global convergence has been prominent in recent years. Good governance is an outcome of strict adherence to well-run boards, accounting standards, transparency and accurate financial disclosures. It is a well-established fact that investors tend to invest in well-run companies with healthy balance sheets and enduring good financial performance. ${ }^{14}$ This underscores the importance of good Corporate Governance. Good Corporate Governance eliminates, among others, conflicts of interests, lack of independence of directors and auditors fraudulent conduct. It can thus be argued the CG codes and legal rules have become the cornerstone of corporate governance as they impose the director's duties and role of shareholders. With the aim of setting the company on a success trajectory, anchored on governance codes and legislative prescripts.

This project attempts to analyse the various CG approaches in the UK and South Africa. Further, points of convergence and divergence are also examined. Though the UK approach on $C G$ is not an omega, however it is common cause that its influence reaches across its borders. No doubt, commonwealth jurisdictions like South Africa, Zimbabwe and many others borrow theirs largely from the UK as UK is seen as a global leader on the codes, post UK Corporate Governance Code. ${ }^{15}$ Thus, the focus and interest on the Anglo-Saxon model of $\mathrm{CG},{ }^{16}$ and bringing to the fore the prominent CG theories, ${ }^{17}$ namely Agency, ${ }^{18}$ separation of ownership and control, ${ }^{19}$ as it was rightly enshrined in the seminal Salomon case, ${ }^{20}$ transaction cost economics (TCE), ${ }^{21}$ stakeholder theory ${ }^{22}$ and steward theory. ${ }^{23}$

\footnotetext{
12 Duane Windsor, 'Tightening corporate governance' (2009) 15 (3) Journal of International Management 306-316 < https://www.kantakji.com/media/3395/w157.pdf> accessed 27 May 2021.

13 Duane Windsor, 'Tightening corporate governance' (2009) 15 (3) Journal of International Management 306-316 $<$ https://www.kantakji.com/media/3395/w157.pdf> accessed 27 May 2021.

14 Bello Lawal, Board Dynamics and Corporate Performance: Review of Literature, and Empirical Challenges. International Journal of Economics and Finance Vol. 41 (2012)

${ }^{15}$ UK Corporate Governance Code Financial Reporting Council, 'The UK Corporate Governance Code' (2016) https://www.frc.org.uk/getattachment/ca7e94c4-b9a9-49e2-a824-ad76a322873c/UK-Corporate-GovernanceCode-April-2016.pdf > accessed 27 May 2021.

${ }^{16}$ Bob Tricker and Christine Mallin, 'Rethinking the Exercise of power over Corporate Entities' (2010) Corporate Governance < https://corporategovernanceoup.wordpress.com/tag/agency-theory/> accessed 27 May 2021.

17 Mallin (n1).

18 Mallin, (n 2) 16-17.

19 Mallin (n 3)

20 Salomon v A Salomon [1897] AC 22.

${ }^{21}$ Mallin ( $\mathrm{n}$ )

22 Mallin ( $\mathrm{n} 5)$

${ }^{23}$ Mallin (n 6)
} 


\section{Aims and Objectives}

The exploratory study has attempted:

- To define Corporate Governance

- To make a comparative analysis of differences and similarities of Corporate Governance in the UK and South Africa.

- To look at the effectiveness of CG codes in these jurisdictions and if there are any weaknesses and strengths and applicable rules and codes.

Accordingly, this study will hopefully contribute to the field of Corporate Governance by bringing the experiences and lessons learnt from these jurisdictions, namely South Africa and the UK. Further, to analyse global impact of the financial crisis.

\section{Background of the Study}

A company is a creature of statute with a distinct legal persona, thus, the exegesis of this paper brings to the fore the importance of good corporate governance in corporations. The Companies Act imposes the directors to act in the best interest of the company by upholding their fiduciary duties. Although the phenomenon of Corporate Governance has been long existing, however, Post Enron ${ }^{24}$ corporate scandals and 2008 recession have forced the global community to look closely to the principles of corporate governance. ${ }^{25}$ Though there is no definite definition of it, however Corporate Governance can be defined as, "the system by which companies are directed and controlled." 26 Thus, Corporate Governance has become a topical discussion in recent years, especially after Enron, ${ }^{27}$ Maxwell (UK), ${ }^{28}$ and Parmalat ${ }^{29}$ cases and other major global financial crisis. Enron was arguably a turning point in the American history of corporate governance and company fraud. Subsequently, various jurisdictions have made corporate law reforms with codes of best practices, among others including the Nigeria SEC Codes, ${ }^{30}$ UK Cadbury Code, ${ }^{31}$ South Africa King Reports, ${ }^{32}$ US

\footnotetext{
${ }^{24}$ Mallin ( 7 )

${ }^{25}$ Mallin (n 8)

${ }^{26}$ Cadbury Report, 1992 < https://www.icaew.com/library/subject-gateways/corporate-governance/codes-andreports/cadbury-report> accessed 26 May 2021.

${ }^{27}$ Enron < https://www.thebalancesmb.com/sarbanes-oxley-act-and-the-enron-scandal-393497> accessed 27 May 2021.

28 Maxwell Sheppard v. Maxwell, 384 U.S. 333 (1966)

${ }^{29}$ Ron Rimkus, 'Financial Scandals, Scoundrels \& Crises92016) CFA Institute $<$ Parmalat

$>$ https://www.econcrises.org/2016/11/29/parmalat/> acessed 27 May 2021.

${ }^{30}$ Nigeria SEC Codes 2009 < http://sec.gov.ng/regulation/rules-codes/> accessed 27 May 2021.

31 UK Cadbury Code 1992< https://www.icaew.com/library/subject-gateways/corporate-governance/codes-andreports/cadbury-report> accessed 27 May 2021.

32 South Africa King Reports < http://www.iodsa.co.za/?kinglll > accessed 27 May 2021.
} 
Sarbanes-Oxley Act. ${ }^{33}$ All these various jurisdictions have a central theme in these codes that is the need of well governed corporations. After all, corporate scandals influence the lives of people and nations.

Various theories of corporate governance are important for this study, which include Agency theory, ${ }^{34}$ transaction cost economics theory, ${ }^{35}$ which looks at the company as governance structure, Stakeholder Theory ${ }^{36}$ looks at the relationship between the company and its various stakeholders like employees and stewardship theory ${ }^{37}$ which focuses on the moral duty of directors/managers to act as "stewards" 38 of the company as they execute their "fiduciary duties." 39 Other significant issues, including cultural diversities between the UK and South Africa will also feature as an important divergent point in this project.

\section{Methodology}

The fundamental basis for this exploratory qualitative examination included the use of purposively sampled/selected literature sources, including literature review on books, articles, case Law and relevant Statutes. Statutes, corporate governance codes and reports like UK Corporate Governance Code, ${ }^{40}$ Greenbury Report (1995), ${ }^{41}$ OECD ${ }^{42}$ Combined Code (1998), ${ }^{43}$ Turnbull Report (1999), ${ }^{44}$ Myners Report (2001, 2008), ${ }^{45}$ Higgs Report (2003), ${ }^{46}$ Revised Turnbull Guidance (2005), ${ }^{47}$ Combined Code (2006), ${ }^{48}$ Combined Code (2008) ${ }^{49}$ have been analysed. In case of the South African jurisdiction, codes like King reports ${ }^{50}$ have been

\footnotetext{
33 US Sarbanes- Oxley Act of 2002.

34 Mallin ( 9 )

${ }^{35}$ Mallin (n 10)

${ }^{36}$ Mallin (n 11)

${ }^{37}$ Mallin (n 12)

${ }^{38}$ Mallin (n 13)

${ }^{39}$ Mallin (n 14)

${ }^{40}$ UK Corporate Governance Code Financial Reporting Council, 'The UK Corporate Governance Code' (2016) https://www.frc.org.uk/getattachment/ca7e94c4-b9a9-49e2-a824-ad76a322873c/UK-Corporate-Governance-

Code-April-2016.pdf > accessed 27 May 2021.

${ }^{41}$ Directors' Remuneration, Report of a Study Group chaired by Sir Richard Greenbury, 17 July 1995.

42 Organisation for Economic Co-operation and Development (1999) > accessed 28 November 2018, defines corporate governance as "a set of relationships between a company's board, its shareholders and other stakeholders. It also provides the structure through which the objectives of the company are set, and the means of attaining those objectives, and monitoring performance, are determined."

43 lbid.

44 Turnbull Committee 1999 revised in 2005.

${ }^{45}$ Paul Myners, 'Institutional Investment in the United Kingdom: A Review' (2001) HM Treasury < http://uksif.org/wp-content/uploads/2012/12/MYNERS-P.-2001.-Institutional-Investment-in-the-United-Kingdom-AReview.pdf > accessed 27 May 2021

46 Derek Higgs, Review of the role and effectiveness of non-executive directors, January 2003.

${ }^{47}$ Turnbull Committee 1999 revised in 2005.

${ }^{48}$ Combined Code 2006.

${ }^{49}$ Combined Code 2008.

50 King IV Report on Corporate Governance in SA <https://www.iodsa.co.za/page/Kinglll> Accessed 27 May 2021.
} 
analysed and a brief look at the Companies Act $2008^{51}$ which borrows heavily from the UK Companies Act 2006, ${ }^{52}$ the latter providing a substantive departure from common law as it codified the director's duties. Thus, ushering legal certainty and judicial clarity on the interpretation of director's duties.

The examination has further included descriptive methods, which include theoretical description of the concepts and questions in articulating the subject area. This project is structured to include an outline of the methodology used, definition of key concepts and concluding a summary of the essence of the research question and other questions that arose for further research.

\section{Corporate governance approaches}

\subsection{CG in the UK}

The evolution of corporate governance in the UK has seen great strides with more emphasis on flexibility that encourages "voluntary compliance," 53 especially from the Cadbury Report ${ }^{54}$ times. UK CG Codes, Legal Rules, and Practices are seen as the bedrock of most global codes. Thus, Corporate Governance Code $2016^{55}$ and other revisions are central codes in the UK, looking at the role and principles of corporate governance, ${ }^{56}$ company as a governance structure $^{57}$ and corporate social responsibility. ${ }^{58}$ The codes states that "the purpose of corporate governance is to facilitate effective, entrepreneurial and prudent management that can deliver the long-term success of the company." 59 Thus, the importance of "corporate constituencies" ${ }^{60}$ as espoused in UK Stewardship Code. ${ }^{61}$ CG became very popular in the UK after many corporate scandals like BCCl, ${ }^{62}$ Maxwell (UK) ${ }^{63}$ and Barings Bank. ${ }^{64}$

\footnotetext{
51 South African Companies Act of 2008.

52 Companies Act 2006.

${ }^{53}$ Andrew Keay, Assessing accountability of boards under the UK Corporate Governance Code, Journal of Business Law (2015).

${ }^{54}$ Sir Adrian Cadbury, Report of the Committee on the Financial Aspects of Corporate Governance (Gee \& Co Ltd 1992).

55 UK the Corporate Governance Code 2016.

56 lbid.

${ }^{57}$ Mallin (15)

58 Stakeholder Theory, Transaction cost economics theory and agency theory.

59 Financial Reporting Council, 'The UK Corporate Governance Code' (2016) https://www.frc.org.uk/getattachment/ca7e94c4-b9a9-49e2-a824-ad76a322873c/UK-Corporate-GovernanceCode-April-2016.pdf > accessed 27 May 2021.

60 Ibid.

${ }^{61}$ Mallin (n 16) 37.

62 Mallin ( 17 )

${ }^{63}$ Mallin (n 18)

${ }^{64}$ Mallin, (n 19) 1.
} 


\subsection{CG in South Africa}

South African law is rooted on the Roman-Dutch law with strong influence of the UK law. Post 1994 democratic South Africa, the development of CG has seen great progress with the adoption of the 'apply-or-explain'65 approach through the various four (4) King reports. CG in South Africa is worldwide known and hailed for its comprehensive and inclusive nature. It sought to align interest of shareholders and of those running the company, in order to create the firm's value and better financial performance. There is also an additional issue of redressing past imbalances through appointment of black people. Thus, the preference of the Agency theory, ${ }^{66}$ notwithstanding its known weaknesses. The Board is seen as the "heart of corporate governance" 67 with the main responsibility to monitor executives and management as they execute their duties in running the affairs of the company. The role of "institutional investors"68 also contributes to compliance and effectiveness as South African companies are part of emerging markets, as such they need investors to capitalize their businesses. Institutional investors are not a preserve of listed companies but their interest is spread across to both listed and unlisted and they continue to exercise their power through their shareholding rights. Institutional investors often exert influence on financial markets which may exacerbate liquidity problems and market volatility. Board diversity, ${ }^{69}$ remuneration of directors ${ }^{70}$ and shareholder interests ${ }^{71}$ are contentious issues, owing to the complex historical factors in South Africa.

\section{Key Issues and applicable Corporate Governance Codes and legal rules}

\subsection{Applicable CG reports and governance Codes in the UK}

The UK has made many reforms to improve the standards of corporate governance, through various codes of conduct. Examples can be drawn from the UK's 1998 Combined Code, ${ }^{72}$ known as "soft law"73 because of its voluntary nature. There are subsequent reports and codes, including but not limited to, Greenbury Report (1995), ${ }^{74}$ Hampel Report (1998), ${ }^{75}$

\footnotetext{
65 Sarkar (n 2) 31.

66 Mallin (n 20)

67 Bello Lawal, Board Dynamics and Corporate Performance: Review of Literature, and Empirical Challenges

(2012) International Journal of Economics and Finance, Caledonian School of Business \& Society Vol. 4, No. 1.

68 Mallin ( $\mathrm{n} 21$ )

69 Mallin (22)

${ }^{70}$ Mallin (23)

${ }^{71}$ Mallin (n 24)

72 UK Combined Code 1998.

${ }^{73}$ Andrew Keay, Assessing accountability of boards under the UK Corporate Governance Code, Journal of

Business Law (2015)

${ }^{74}$ Directors' Remuneration, Report of a Study Group chaired by Sir Richard Greenbury, 17 July 1995.

${ }^{75}$ Hampel Committee on Corporate Governance Report, January 1998.
} 
Combined Code (1998), ${ }^{76}$ Turnbull Report (1999), ${ }^{77}$ Stewardship Code (2010), ${ }^{78}$ Davies Report $(2011,12-15),{ }^{79}$ UK Corporate Governance Code (2012), Stewardship Code (2012). ${ }^{80}$

\subsection{Applicable CG reports and governance Codes in South Africa}

Post democratic South Africa, the prevalent of King reports have centrally defined corporate governance principles. These are King I (1992), ${ }^{81}$ King II (2002), ${ }^{82}$ King III (2010), ${ }^{83}$ and the latest one being King IV. ${ }^{84}$ These reports are known for attracting institutional investors, although often criticised for insisting on having a local partner to their share structure. The governance usually includes unitary boards structure ${ }^{85}$ dispersed ownership structure,${ }^{86}$ outsider system ownership and control structures. ${ }^{87}$

\subsection{Strengths and weaknesses in the UK}

UK codes compare well with international best practices ${ }^{88}$ however compliance is still a problem. Other difficulties with CG in the UK, like in many jurisdictions, is that CG is not a 'shoe size that fits' all companies, others are big or small, others are socially responsible firms. One of the notable strengths is the "voluntary compliance," strength is however often seen as a weakness for high levels of non-compliance because companies don't feel compelled with little or no consequences because of the nature of voluntary compliance.

One of the greatest criticisms of CG theories is that their focus is largely on public corporations especially those listed in London stock exchange and thus, leave behind small and medium enterprises. The cultural diversity is also a cause for concern as UK has people from minority groups that aren't well represented in other sectors.

\footnotetext{
76 Ibid.

77 Turnbull Report 1999.

78 Stewardship Code 2012

79 lbid.

${ }^{80}$ Mallin (n 25)

81 Mallin (n 26) 371

82 Mallin (n 27) 371, described as the "most comprehensive and most innovative reports published to date anywhere......."

83 M R Roe, Political Determinants of Corporate Governance (Oxford University Press 2003).

84 Institute of Directors South Africa, ' King IV Report on corporate Governance For South Africa 2016' < https://www.adamsadams.com/wp-content/uploads/2016/11/King-IV-Report.pdf> accessed 26 May 2021.

85 David Block and Anne-Marie Gerstner, 'One-Tier vs Two-Tier Board Structure: A Comparison Between the United States and Germany' (2016) 1 Comparative Corporate Governance and Financial Regulation 6 < https://scholarship.law.upenn.edu/cgi/viewcontent.cgi?article=1001\&context=fisch 2016> accessed 26 May 2021.

${ }^{86}$ Roe (n 1) 45.

${ }^{87}$ Roe (n 2) 45.

88 lbid.

${ }^{89}$ Andrew Keay, Assessing accountability of boards under the UK Corporate Governance Code, Journal of Business Law (2015).

${ }^{90}$ lbid.
} 


\subsection{Strengths and Weaknesses in South Africa}

South Africa's King Reports, ${ }^{91}$ highlight corporate governance and the interests of shareholders and various stakeholders. Contentious issues like cultural diversities, gender representation and minority group presentations in Board is a contentious issue, some scholars arguing that it has an effect in good corporate governance. South Africa comes from a history of segregation, thus corporate CG codes are designed to redress these past disparities, although not without difficulty. Diversity is one of the greatest strengths which contribute effectively to good and sound decision-making, reflective of all people. Thus, women representations in Boards is seen as an important consideration.

\subsection{Impact of the global financial crisis on corporate governance}

The global financial crisis is seen to have contributed to the development of good corporate governance. Companies in various jurisdictions had to reflect on how to do business better. Governments had to consider statutory interventions in jurisdictions like the US as they enacted US Sarbanes- Oxley Act, ${ }^{92}$ as a response to the Enron scandals. South Africa enacted the Public Finance Management Act (PFMA) to regulate governance.

\section{Conclusion}

Although it is hard to measure its tangible successes, however corporate governance remains important for a company's success and the efficient use of its resources. The effects of various corporate scandals and recession have contributed immensely to the development of corporate governance in the UK and South Africa. While there are similarities between the UK and South Africa CG, but some differences are observed. Thus, from the preliminary literature review the UK adopted a 'comply or explain approach, ${ }^{93}$ while South Africa adopted 'apply-or-explain'94 approach. From the study, it can be concluded that in both jurisdictions, Good corporate governance is an important tool in curbing poor governance and limiting scandals in corporations. However, the real significance of good governance may well lie with the question of its enforceability. Thus, a company is entitled, in the words of Upjohn LJ, "to the undivided loyalty of its directors." 95

\footnotetext{
91 South Africa King Reports < http://www.iodsa.co.za/?kinglll > accessed 26 May 2021.

92 US Sarbanes- Oxley Act of 2002.

${ }^{93}$ Subrata Sarkar, 'The Comply-or-Explain Approach for Enforcing Governance Norms' (2015) Indira Gandhi Institute of Development Research Mumbai 1 http://www.igidr.ac.in/pdf/publication/WP-2015-022.pdf accessed 27 May 2021.

94 Ibid.

95 Boulting v Association of Cinematograph, Television and Allied Technicians [1963] 2 QB 606
} 


\section{References}

Anguilar, L. A., 2015. 'The Important Work of Boards of Directors'. New York, 12 Annual Boardroom Summit and peer Exchange.

Correa, R. \& Lel, U., 2013. Say on Pay Laws, Executive Compensation, Pay Slice, and Firm Valuation around the World,. JEL Classification Codes: G15, G34, G38, M12.

Frye, M. B., Nelling, E. \& Webb, E., 2006. Executive Compensation in Socially Responsible Firms. Corporate Governance, 14(5), pp. 446-455. https://doi.org/10.1111/j.1467-8683.2006.00517.x .

Gillette, B., Noe, T. \& Robello, M., 2008. B Gillette, Thomas H Noe and Michael J Robello, 'Board Structures Around the World: An Experimental Investigation'. Review of Finance, 12(1), p. 93-140.

Higgs, D., 2003. Review of the role and effectiveness of non-executive directors, s.I.: s.n.

Keay, A., 2015. Assessing accountability of boards under the UK Corporate Governance Code. Journal of Business Law .

Mallin, C. A., 2016. Corporate Governance. 5th ed. Oxford: Oxford University Press .

Myners, P., 2001. Institutional Investment in the United Kingdom. HM Treasury.

Roe, M. R., 2003. Political Determinants of Corporate Governance. Oxford : Oxford University Press .

Sarkar, S. .., 2015. The Comply-or-Explain Approach for Enforcing Governance Norms, Mumbai: Indira Gandhi Institute of Development Research.

Tricker, B. \& Mallin, C., 2010. Rethinking the Exercise of power over Corporate Entities'. Corporate Governance.

\section{Other Resources}

\section{Case Law}

Boulting v Association of Cinematograph, Television and Allied Technicians [1963] 2 QB 606

Salomon v A Salomon [1897] AC 22

\section{Statutes}

UK Corporate Governance Code

UK Companies Act of 2006

South African Companies Act of 2008

Public Finance Management Act (PFMA) of 1999

US Sarbanes- Oxley Act of 2002

Company Directors Disqualification Act of 1986 
Insolvency Act of 2000

Small Business, Enterprise and Employment Act of 2015

Companies Amendment Act, 3 of 2010

Broad-Based Black Economic Empowerment Act of 2003

\section{SOFT Laws}

UK Corporate Governance Code Financial Reporting Council, 'The UK Corporate Governance Code' (2016) https://www.frc.org.uk/getattachment/ca7e94c4-b9a9-49e2-a824ad76a322873c/UK-Corporate-Governance-Code-April-2016.pdf

Financial Reporting Council, 'June 2008 Changes to the Corporate Governance Combined Code' (2008) < https://www.frc.org.uk/getattachment/51661579-e055-426a-b0fa3e2090c883e3/June-2008-Changes-to-the-Combined-Code.pdf> accessed 21 May 2021

Financial Reporting Council, 'The UK Corporate Governance Code' (2014) < https://www.frc.org.uk/getattachment/59a5171d-4163-4fb2-9e9d-daefcd7153b5/UK-

Corporate-Governance-Code-2014.pdf> accessed 21 May 2021

\section{ABOUT AUTHORS}

*Dr King Costa is a Research Professor and Executive Dean at the Global Centre for Academic Research. He is a lifetime member of the Asian Qualitative Research (AQRA), based in the Philippines; The Society of Professors of Education, based in the USA; Southern African Institute for Management Scientists, South African Research and Innovation Association and the Society for Industrial and Organisational Psychology of South Africa. $\mathrm{He}$ also serves as a member of the Scientific Committee at the World Conference on Qualitative Research, $\mathrm{He}$ is an author of several articles, pedagogies and book chapters. He may be contacted at costak@researchglobal.net

**Ms Thelela Ngcetane-Vika is a Social Scientist and PhD researcher at the Global Centre for Academic Research. Her research focus is on women empowerment, development, equality and justice. As a bricoleure, she uses transformative approaches to blend both the practice of law and development of women, as a research agenda. As an advocate for social justice, she is involved in action research for championing human rights issues in Africa. She is an 
assessor for the Women Leadership Programme at the Oxford University's Saïd Business School.

She is also an author of "Servant for All Seasons" published in 2021 and has completed a book chapter on Nelson Mandela and his legal jurisprudence to be published in the UK later in 2021. She may be contacted at thelela.vika@gmail.com 